\title{
Current advances in the study of diabetic cardiomyopathy: From clinicopathological features to molecular therapeutics (Review)
}

\author{
LIN SUN ${ }^{1}$, MING YU ${ }^{2}$, TONG ZHOU ${ }^{1}$, SIWEN ZHANG ${ }^{1}$, GUANGYU HE $^{1}$, GUIXIA WANG ${ }^{1}$ and XIAOKUN GANG ${ }^{1}$ \\ ${ }^{1}$ Department of Endocrinology and Metabolism, The First Hospital of Jilin University; \\ ${ }^{2}$ Department of Cardiology, China-Japan Union Hospital of Jilin University, Changchun, Jilin 130021, P.R. China
}

Received October 8, 2018; Accepted May 29, 2019

DOI: $10.3892 / \mathrm{mmr} .2019 .10473$

\begin{abstract}
The incidence of diabetes mellitus has become a major public health concern due to lifestyle alterations. Moreover, the complications associated with diabetes mellitus deeply influence the quality of life of patients. Diabetic cardiomyopathy (DC) is a type of diabetes mellitus complication characterized by functional and structural damage in the myocardium but not accompanied by coronary arterial disease. Currently, diagnosing and preventing DC is still a challenge for physicians due to its atypical symptoms. For this reason, it is necessary to summarize the current knowledge on DC, especially in regards to the underlying molecular mechanisms toward the goal of developing useful diagnostic approaches and effective drugs based on these mechanisms. There exist several review articles which have focused on these points, but there still remains a lot to learn from published studies. In this review, the features, diagnosis and molecular mechanisms of DC are reviewed. Furthermore, potential therapeutic and prophylactic drugs are discussed.
\end{abstract}

\section{Contents}

1. Introduction

2. Epidemiology and features of DC

3. Diagnosis of DC

4. The pathogenesis of DC

5. The molecular mechanism of DC

6. Treatment of diabetic cardiomyopathy

7. Conclusions

Correspondence to: Dr Guixia Wang or Dr Xiaokun Gang, Department of Endocrinology and Metabolism, The First Hospital of Jilin University, 71 Xinmin Street, Changchun, Jilin 130021, P.R. China

E-mail: gwang168_1@163.com

E-mail: insightful@126.com

Key words: diabetes mellitus, diabetic cardiomyopathy, molecular mechanisms, characteristics, diagnosis, review

\section{Introduction}

Cardiovascular disease has become a major global health issue which is attributed to multiple factors, including diet, smoking, lifestyle and environmental change (1). The sharp increase in the diabetic population has been proposed to be closely associated with the rising prevalence of cardiovascular disease. According to statistics, the number of diabetic patients worldwide has currently increased to 1.8 billion, and has doubled since the year 2000. It is predicted that the global diabetes population will increase from 285 million to 439 million between 2010 and 2030 (2). Compared to non-diabetic individuals of the same age, the risk of heart failure in male and female diabetic patients is increased 2-fold and 5-fold, respectively (3).

Diabetic cardiomyopathy (DC) was firstly proposed by Rubler et al (4) in 1972. At that time, four cases of heart failure in patients with diabetic glomerulosclerosis were autopsied but no other causes of heart failure other than diabetes were found. Thus, the concept of DC was proposed. DC is currently defined as an obvious change in myocardial structure and function in diabetic patients, excluding ischemic diseases, hypertension, or other diseases that can induce myocardial damages $(5,6)$.

In a recent review, the correlation between hyperinsulinemia or insulin resistance, cardiac dysfunction and hyperglycemia was discussed (7). The authors also summarized the recent advances in the research on DC, its pathogenesis and the underlying molecular mechanisms, and the promising prophylactic and curative approaches (7). Here, we aimed to summarize the current advances in DC with strong emphasis on the molecular mechanisms.

\section{Epidemiology and features of DC}

The incidence of DC is not yet clear due to a lack of large data of outcomes from different populations with diabetes mellitus (DM). A higher prevalence rate (40 to 60\%) of diastolic dysfunction in type $2 \mathrm{DM}$ (T2DM) patients has been reported in the literature (8). Autopsies have revealed that DC has a number of pathological features, including cardiomyocyte hypertrophy, interstitial fibrosis, periodic-acid-Schiff (PAS)-positive infiltration, thickening of the basal membrane of coronary arterioles, and myocardium microvascular lesions (9-11). The 
structural changes in DC are characterized by a near-normal left ventricular end-diastolic volume, increased left ventricular weight and thickness, cardiac hypertrophy and fibrosis, and fat deposition $(12,13)$. The functional alterations include an impaired diastolic function without obvious decreased systolic function, and a decreased ventricular wall elasticity (14).

\section{Diagnosis of DC}

Currently, the diagnosis of early DC has not yet made substantial progress, and the mainstream methods for DC diagnosis include imaging methods and serum biomarkers. The pathological changes in early DC include cardiac hypertrophy, fibrosis and lipid deposition. Abnormal cardiac function is characterized by early diastolic dysfunction and late systolic dysfunction. The diagnostic criteria for DC refer to the method of Tarquini et al (15), which are mainly as follows: Presence of DM, exclusion of coronary artery disease, valvular or congenital heart disease, exclusion of hypertensive heart disease, exclusion of viral myocarditis by endomyocardial biopsy and left ventricular ejection fraction (LVEF) $<50 \%$, left ventricular end-diastolic volume index (LVEDVI) $>97 \mathrm{ml} / \mathrm{m}^{2}$. For distinguishing these pathological features, the following methods can be employed.

Echocardiography and Doppler imaging. In the early stages of DC, echocardiography can be the prior method for assessing cardiac structural and functional abnormalities in diabetic patients due to its inexpensive and non-invasive advantages $(16,17)$. Tissue Doppler imaging (TDI) measures left ventricular isovolumetric diastolic time, early mitral annular diastolic motion velocity (Ve), late diastolic motion velocity (Va) and the Ve/Va ratio (18). By comparing these data, cardiac diastolic function images can be divided into 2 types: Restricted mitral flow pattern and unrestricted mitral flow pattern. Unrestricted mitral flow patterns include normal, impaired and false normalization (16-18). This technique has high sensitivity and specificity, and is currently considered to be a reliable method for evaluating left ventricular diastolic function in patients with coronary heart disease $(19,20)$. Intravenous contrast echocardiography is based on the elevated sonic reflectivity of contrast agents; therefore, the contrast injection can aid in the accurate monitoring of the endocardial borders, and the measuring of ventricular size and ventricular motion. The complement of intra-cardiac echocardiography (ICE) into 2D-echocardiography provides an improved evaluation of left ventricular function (21). A previous study demonstrated that alterations in the contractility, systolic function and microcirculation can be well observed via ICE in T1DM murine models (22).

Speckle tracking echocardiography (STE) is a novel imaging technique for achieving mechanical deformation of the myocardia (23). It uses the images acquired from echocardiography to quantify the inter-pixel distance during the cardiac cycle. Therefore, morphological alterations of myocardial deformation can be detected $(23,24)$. It has been demonstrated that the diabetic microangiopathy in T2DM patients is closely associated with the myocardial deformation through 3D-STE (25). In this regard, $24 \%$ of diabetic patients are diagnosed with systolic functional impairment by $2 \mathrm{D}-\mathrm{STE}$, which cannot be detected through conventional methods (26).

Magnetic resonance imaging (MRI). MRI is a highly sensitive tool that not only detects abnormal wall motion and cardiac hypertrophy, but also provides information concerning arrhythmias and cardiomyopathy. Rijzewijk et al (27) believe that contrast-enhanced MRI can be used to predict the progression of ventricular arrhythmias, myocardial steatosis and heart failure in patients with a history of ischemic heart disease. Cardiac MRI can detect myocardial metabolic abnormalities through different radioactive elements and positron emission tomography (PET) (28).

Cardiac catheterization and coronary angiography. Cardiac catheterization is currently the best technique for assessing intracardiac hemodynamics and is considered to be the gold standard for the diagnosis of diastolic cardiac dysfunction, but it is not widely used due to its invasiveness $(29,30)$. Left and right ventricular catheterization can be employed to assess left ventricular end-diastolic pressure and mean pulmonary arterial wedge pressure, respectively $(29,30)$. The left ventricular end-diastolic pressure $>16 \mathrm{mmHg}$ or a pulmonary capillary wedge pressure $>12 \mathrm{mmHg}$ can be used as criteria for the diagnosis of diastolic dysfunction (31). Coronary angiography is mainly used to determine coronary artery stenosis, which tends to occur in late DC (32-34).

\section{Serum biomarkers}

Matrix metalloproteinases (MMPs) and matrix metalloproteinase inhibitory factors. Previous studies have found that extracellular matrix proteins are associated with persistent ventricular remodeling $(35,36)$. MMPs are endogenous proteolytic enzymes that degrade type I and type III collagen during the development of heart failure, thereby promoting myocardial fibrosis; they can also affect the expression of microRNAs (miRNAs) and cause myocardial contractile dysfunction (37-39). During the process of myocardial fibrosis, serum MMPs (especially MMP-9) are increased, while tissue inhibitory factors of MMPs are decreased (40). Ban et al (41) measured serum MMP-7 in patients with DC via enzyme-linked immunosorbent assay (ELISA), and found that MMP-7 was significantly higher in patients with diastolic dysfunction than in patients with normal diastolic functions.

Homocysteine (Hcy). Hcy is a type of sulfur-containing amino acid that is an intermediate metabolite of methionine. It has been reported that plasma Hcy levels are positively correlated with the risk of cardiovascular events (42). For every $5 \mu \mathrm{mol} / 1$ increase in plasma Hcy, the risk of ischemic heart disease is increased by $32 \%$, and for each $5 \mu \mathrm{mol} / 1$ decrease, the risk is reduced by $16 \%$ (43). Previous studies have shown that high Hcy (HHcy) and hyperglycemia can both lead to DC by inducing oxidative stress and reducing the level of peroxisome proliferator-activated receptor $\gamma$ (PPAR- $\gamma$ ) (44-46), but whether there is a synergistic mechanism between them is not yet clear. Mishra et al (44) found that in HHcy and hyperglycemic murine models, the ventricular end-diastolic diameter was increased, and PPAR- $\gamma$, tissue metalloproteinase- 4 , and 
thioredoxin inhibitor levels were decreased, whereas those of MMP-9 were increased, suggesting that endogenous Hcy reduces the expression of PPAR- $\gamma$ and induces the decoupling of endothelial-myocytes (EMs), resulting in diastolic dysfunction and further progression of DC.

Other biomarkers. The serum procollagen type III aminopeptide (PIIINP) level reflects the metabolism of type III collagen. A previous study proposed that PIIINP is an important indicator of early left ventricular dysfunction in obese patients with insulin resistance (47). Epshteyn et al (48) found that $96 \%$ of diabetic patients with left ventricular dysfunction had increased levels of brain natriuretic peptides (>90 pg/ml). Cardiac troponin is a type of protein released from ischemic or inflammatory disease-damaged cardiomyocytes. Russell et al (49) reported that the levels of troponin T were elevated in the blood of neonates with congenital cardiomyopathy or cardiac insufficiency in mothers with diabetes. However, in adult DC patients, its clinical significance remains uncertain.

Early diagnosis and intervention of DC can slow disease progression, and provide an improved prognosis. Therefore, a combination of multiple techniques for the diagnosis of DC is recommended. For example, a combination of NT-proBNP quantification and echocardiography has more reliable diagnostic value for DC diagnosis than either technique alone (50). In addition, further identification of novel biomarkers is needed, such as microRNAs and long non-coding RNAs (lncRNAs).

\section{The pathogenesis of $\mathrm{DC}$}

Hyperglycemia. Hyperglycemia plays a key role in the pathogenesis of DC. Hyperglycemia has been shown to directly or indirectly damage cardiomyocytes, fibroblasts and endothelial cells via the accumulation of reactive oxygen species (ROS) (51). Hyperglycemia can increase the production of ROS through the electron chain, which can induce apoptosis of cardiomyocytes (52). ROS activate polyADP-ribose polymerase (PARP), consequently causing an increase in glycosylation and inhibition of glyceraldehyde phosphate dehydrogenase (GAPDH), which transforms the glycolysis process into a cascade of cardiomyocyte injury (53). This process involves increased production of glycation end products, activation of hexosamine pathways, and increased production of protein kinases (PKCs). High levels of ROS, PARP, glycation end products, and aldose reductase production induced by hyperglycemia can lead to cell apoptosis $(54,55)$.

Lipotoxicity. In the diabetic state, increased hepatic fat synthesis and fat lysis in adipocytes promote the formation of circulating fatty acids and triglycerides $(56,57)$. The transportation of fatty acids into cardiomyocytes requires the intermediation of insulin, hyperinsulinemia and hyperlipidemia can increase the fatty acid transportation, and thus induce lipotoxicity in cardiomyocytes (58). The following three mechanisms are included in lipotoxicity: i) Increased production of ROS [increased levels of oxidized fatty acids can increase the mitochondrial membrane potential and thus increase production of $\operatorname{ROS}(55,59)]$; ii) increased production of ceramide [ceramide is a sphingomyelin that induces apoptosis of cardiomyocytes by inhibiting the mitochondrial respiratory chain (59)]; and iii) effects on myocardial contractile function. Elevated fatty acid levels in cardiomyocytes can cause the opening of potassium channels, resulting in shortening of the action potential duration and opening of L-type calcium channels, ultimately affecting the calcium storage of calcium pump of sarcoplasmic reticulum and impairing myocardial contractile function $(60,61)$. Excessive fatty acid uptake and metabolism not only cause the accumulation of intermediate metabolites of fatty acids, increase the oxygen demand and uncoupling of mitochondria, but also increase the production of ROS, reduce the synthesis of ATP, cause mitochondrial dysfunction, and increase apoptosis (62). Therefore, hyperlipidemia plays a core role in the pathogenesis of DC.

Hyperinsulinemia. Insulin resistance and subsequent hyperinsulinemia are typical pathophysiological characteristics of diabetes mellitus. In the normal heart, 2/3 of the energy provided for myocardial contraction is derived from fatty acid oxidation, and the remaining $1 / 3$ is derived from glucose and lactic acid metabolism (63). Glucose utilization is significantly limited in patients with hyperinsulinemia or insulin resistance, therefore myocardial energy metabolism is more dependent on fatty acid oxidation (64). Moreover, hyperinsulinemia induces cardiomyocyte hypertrophy through a variety of mechanisms. Multiple epigenetic and genetic changes caused by hyperinsulinemia lead to the dysregulation of extracellular and intracellular protein expression, especially extracellular matrix proteins, leading to cardiomyocyte hypertrophy and myocardial fibrosis (65).

Disruption of calcium homeostasis. A balanced regulation of calcium metabolism in cardiomyocytes guarantees normal cardiac contractility (66). Oxidative stress, aggregation of long-chain acetylcarnitine, and changes in lipid membrane components can affect myocardial calcium homeostasis (66-68). Recent reports have shown that calcium pump ATPase, sodium-potassium ATPase and sodium-calcium exchange, and changes in ryanodine receptor function are involved in the pathogenesis of DC $(69,70)$.

Renin-angiotensin-aldosterone system abnormalities. The mechanism of the renin-angiotensin-aldosterone system (RAAS) in the development of diabetes to heart failure has long been known $(71,72)$. Research has confirmed that upregulation of the RAAS system in diabetic patients is closely related to cardiac hypertrophy and fibrosis (71-75). Angiotensin directly acts on cardiomyocytes and cardiac fibroblasts via angiotensin receptor-1, causing cardiac hypertrophy and fibrosis (76).

\section{The molecular mechanism of DC}

The main characteristic of DC is the disorder of energy metabolism, which is caused by glucose toxicity, lipotoxicity and the dysregulation of mitochondrial function (12). P53 and cytochrome $\mathrm{C}$ oxidase 2 (SCO2) are important regulators of the mitochondrial respiratory chain, which play an essential role in the pathogenesis of DC (12,77-80). In a diabetic 
condition, the production of ROS activates the $\mathrm{P} 53 / \mathrm{SCO} 2$ signaling system in cardiomyocytes, thereby increasing the oxygen consumption of mitochondria, and causing excessive production of ROS and lipid deposition, which induce cardiac function insufficiency (81).

In order to maintain the efficient function of the myocardium, the $\beta$-adrenergic receptors of cardiomyocytes of diabetic patients are activated, promoting the synthesis of nicotinamide adenine dinucleotide phosphate oxidase and ROS; this pathway mediates myocardial reformation (82-84). The significant factors involved in the development of myocardial reformation and heart failure are p38 mitogen-activated protein kinase and heat shock protein-27, which are both phosphorylated during the process (85).

In a diabetic condition, a series of signaling pathways are activated and involved in cardiomyocyte hypertrophy and interstitial fibrosis. For example, in the case of acute hyperglycemia, mannoses bind to coagulins and the coagulin-complements, which is an important mechanism leading to vascular dysfunction and cardiomyopathy $(86,87)$. The level of serum transforming growth factor- $\beta 1$ (TGF- $\beta 1$ ) is also significantly reduced (88). Thrombospondin-1 activates the potential TGF- $\beta 1$ complex in DC, stimulating cardiomyocytes to secrete collagen fibers III (89). The nuclear factor $\kappa B$ (NF- $\mathrm{KB}$ ) pathway has also been found to promote the pathogenesis and progression of DC in diabetic animal models. This signaling pathway is involved in oxidative stress, inflammation, endothelial dysfunction, cardiac hypertrophy and fibrosis (90). Cardiomyocytes contain numerous messenger systems to regulate their normal physiological functions, and these messenger systems produce synergistic or antagonistic effects. Diabetes almost simultaneously causes lesions in these messenger systems, making the condition more complex. The signaling pathways involved in the pathogenesis of DC are described below.

Nrf2-ARE signaling pathway. An antioxidant response element (ARE) is a promoter sequence located at the 5 'end of the protective gene such as superoxide dismutase (SOD) or glutathione S-transferase (GST), and is a specific DNA-promoter-binding sequence that can be activated by a variety of oxidative and electrophilic compounds, thereby activating phase II detoxification enzymes and antioxidant enzyme gene expression, and protecting normal tissues (91). NF-E2 related factor 2 (Nrf2) is a transcriptional factor that regulates the transcriptional activity of its gene by binding to the 5 ' end ARE sequence of its own gene (92). It is believed that Nrf2 plays a key role in cellular oxidative injury protection and the regulation of cell sensitivity to stress. Nrf2 upregulates the expression of antioxidant genes; thus, activation of $\mathrm{Nrf} 2$ is beneficial for cells to resist oxidative stress (93). Yoh et al (94) found that hyperglycemia and oxidative stress can accelerate renal injury, and Nrf2 is an important factor in preventing the occurrence of diabetic complications. He et al (95) found that hyperglycemia damages cardiomyocytes through the ROS system and induces DC. Nrf2-depleted rats can quickly develop DC and exhibit increased levels of glucose-induced apoptosis at lower concentrations, therefore, $\mathrm{Nrf} 2$ has been suggested to be a key regulator of ARE's anti-oxidative stress and can prevent the progression of DC.
Hemeoxygenase 1 (HO-1), or heat shock protein 32 (HSP32), is a stress protein induced by a variety of factors, and oxidative stress can activate its expression. HO-1 induction is considered to be a common marker of oxidative stress (96). Shi et al (97) showed that activation and intra-nuclear expression of Nrf2 protein can promote the expression of anti-oxidative protein $\mathrm{HO}-1$, which can significantly reduce renal oxidative stress injury in type 1 diabetic mice. The overexpression of HO-1 can protect the myocardia from ischemia/reperfusion injury, and bilirubin produced by HO-1 can protect cardiac function under an ischemic condition (98-102). Therefore, HO-1 is an important antioxidant protease of the Nrf2-ARE pathway. The Nrf2-ARE pathway is a key approach for the body to resist oxidative stress injury. Oxidative stress is an important mechanism of the pathogenesis of DC. Resisting oxidative stress and scavenging ROS are potent strategies for the treatment of DC and have been demonstrated to be an effective anti-oxidative stress enzyme system in vivo, and also an important cardioprotective factor for the prevention and treatment of DC. Activation of Nrf2 is a key step in cellular antioxidative stress. It is important to elucidate whether HO-1 exerts cardioprotective effects against DC by activating the Nrf2-ARE pathway (98).

TGF- $\beta 1 /$ Smad signaling pathway. TGF- $\beta 1$ and its downstream Smad proteins are involved in the pathological process of myocardial interstitial fibrosis and cardiac hypertrophy (103). In normal hearts, the levels of TGF- $\beta 1$, type I and type III collagen are extremely low, while diabetic hearts are stimulated by multiple factors such as hyperglycemia, local renin-angiotensin system (RAS), and oxidative stress inflammation. Therefore, the expression of TGF- $\beta 1$ is upregulated and eventually leads to the differentiation of cardiac fibroblasts into myofibroblasts, which also induces the over-synthesis of collagen, fibronectin and proteoglycans (104). The process of myocardial fibrosis is accompanied by upregulation of TGF- $\beta 1$ and its downstream Smad2 and Smad3 proteins (105-111). In vascular smooth muscle cells, TGF- $\beta 1$ promotes the phosphorylation of Smad2 and Smad3 to form a Smad4 trimer (112). This complex translocates into the nucleus and binds to Smad-associated DNA sequences to promote the transcription of fibrogenic factors such as fibronectin and type I collagen; TGF- $\beta 1$-mediated gene expression in human fibroblasts depends on the presence of Smad3 (105-112). In Smad3 gene-deficient mice, myocardial fibrosis can be reduced by $60 \%$, indicating that Smad3 is essential for the development of myocardial fibrosis (113). At present, myocardial fibrosis still lacks effective treatment methods. In-depth study of the role of TGF- $\beta 1 /$ Smad signal transduction pathways in diabetic myocardial fibrosis is expected to provide new and effective therapies for the treatment of DC.

$N F-\kappa B$ signaling pathway. The NF- $\kappa \mathrm{B}$ signaling pathway mainly mediates inflammatory responses. It has been shown that NF- $\mathrm{KB}$ can activate the expression of inflammatory factors such as interleukin (IL)-1, tumor necrosis factor (TNF) and interferon (IFN), which in turn can promote activation of $\mathrm{NF}-\kappa \mathrm{B}$ bypass (114). The activation of the NF- $\kappa \mathrm{B}$ signaling pathway is closely related to the occurrence of cardiovascular disease in diabetes, and is an important intermediate link in 
various signaling pathways in the pathogenesis of diabetic vascular complications (115). Excessive glucose in diabetic patients causes non-enzymatic glycation, producing advanced glycation end products (AGEs) that bind to receptors of AGEs and release large amounts of ROS to activate NF- $\kappa \mathrm{B}$ translocation into the nucleus, which in turn initiates transcription of inflammatory factors such as TNF- $\alpha$, ultimately leading to damage of cardiovascular endothelial cells and proliferation of smooth muscle cells, subsequently promoting cardiovascular disease in diabetes (116-127).

At present, it is believed that the pathogenesis of DC is related to inflammation. Feng et al (128) studied myocardial ischemia-reperfusion injury in rats and found that knocking out the MyD88 gene reduced the myocardial infarction size and improved cardiac function compared to wild-type mice. Furthermore, less inflammatory cell infiltration and lower expression of monocyte chemoattractant protein-1 (MCP-1) and intercellular adhesion molecule-1 (ICAM-1) were found in MyD88-deficient mice, suggesting that the knockdown of MyD88 attenuates the NF- $\mathrm{B}$ activation during ischemia-reperfusion.

PKC signaling pathway. Protein kinase C (PKC) is a family of serine/threonine kinases that are widely present in cells. Most of the neurotransmitters, hormones and growth factors can activate PKC through activating phospholipase $\mathrm{C}$, which produces a lipid-derived secondary messenger (such as diacylglycerol) that phosphorylates the serine/threonine residue of the target protein (129). Previous studies have found that excessive activation of PKC can lead to cardiac hypertrophy and fibrosis, suggesting that PKC inhibitors may prevent and delay cardiac hypertrophy and myocardial fibrosis $(130,131)$. Hyperglycemia increases the de novo synthesis of diacylglycerols in cardiomyocytes, vascular smooth muscle cells and endothelial cells, which in turn activates PKC. In addition, $\mathrm{Ca}^{2+}$, angiotensin, endothelin, vascular endothelial growth factor (VEGF) and osmotic factors can activate PKC. The possible mechanism is that the above factors bind to the cell membrane receptors, and diacylglycerol is activated by membrane phospholipids to activate PKC $(130,131)$. Similarly, the PKC inhibitory therapy should be an essential part of DC treatment. PKC inhibitors have been initially used in the clinical treatment of diabetic vascular complications, but their long-term efficacy and side effects still need to be further observed (132-135).

PPARs. Several PPAR isoforms, including PPAR- $\alpha$, PPAR- $\beta / \delta$, and PPAR- $\gamma$, have been shown to be expressed in cardiomyocytes and act as key regulators for glucose and lipid metabolism, and energetic homeostasis. Interestingly, they are also involved in other cellular events such as inflammation and oxidative stress (136). PPAR- $\alpha$ is relatively highly expressed in the heart, and its activation influences cellular free fatty acid (FFA) uptake and mitochondrial FFA oxidation (137). PPAR- $\alpha$ regulates the assembly and transport of lipoproteins, and regulates the defenses of both oxidant and anti-oxidant. Previous research has shown that overexpression of PPAR- $\alpha$ results in decreased sarcoplasmic reticulum $\mathrm{Ca}^{2+}$ uptake, contractile dysfunction, left ventricular hypertrophy and increased B-type natriuretic peptide (138). Conversely, depletion of PPAR- $\alpha$ prevents fasting-induced FFA metabolic gene expression and enhances glucose metabolism (139). With the progression of DC, long-term exposure to increased FFAs was found to result in reduced PPAR- $\alpha$ expression, which was shown to further injure the cardiac function by inhibiting FFA oxidation and increasing intracellular lipid accumulation in rodent cardiomyocytes $(140,141)$. However, clinical studies have suggested that PPAR- $\alpha$ is not significantly overexpressed in the cardiomyocytes of patients with type 2 diabetes mellitus $(142,143)$. The activation of PPAR- $\alpha$ and the following FFA oxidation in cardiomyocytes under DC situation may act as a compensatory mechanism for substrate supply. Furthermore, a reduction in PPAR- $\alpha$ in advanced disease may have maladaptive consequences in terms of cardiac metabolism, including glucotoxicity and functional cardiac abnormalities. The role of PPAR- $\alpha$ in the progression of cardiac function decrease in DC has not been fully understood and warrants further investigation. Similarly, PPAR- $\beta / \delta$ isoforms are also abundantly expressed in cardiomyocytes and can regulate FFA metabolism (144). Enhanced PPAR- $\beta / \delta$ signaling promotes FFA metabolism and vice versa. Additionally, PPAR- $\gamma$ provides anti-hypertrophic and anti-inflammatory effects in cardiocytes (145). PPAR- $\gamma$ agonists promote insulin sensitivity and enhance cardiomyocyte glucose intake (136). Therefore, PPAR- $\gamma$ may help maintain glucose and FFA metabolism, and can protect cardiac function.

MAPK and JNK activation. MAPK overactivation has been reported to contribute to the pathogenesis of DC and cardiac dysfunction. Erk1/2, p38 MAPK, and JNKs are 3 essential MAPK members that regulate cardiomyocyte growth, hypertrophy and remodeling (146-150). Increased phosphorylation of Erk1/2 and p38 MAPK was observed in streptozotocin-induced DC models (151). Previous research has demonstrated that obesity- or insulin resistance-induced heart failure is associated with the overactivation of S6 kinase 1 and Erk1/2 signaling $(152,153)$. JNK can be activated under the conditions of oxidative stress and inflammation (154). In turn, enhanced JNK signaling in the diabetic heart contributes to oxidative stress, endoplasmic reticulum stress and interstitial fibrosis $(4,154)$. In contrast, inhibition of JNK phosphorylation by a curcumin analog was found to prevent high glucose-induced inflammation and apoptosis in diabetic hearts $(154,155)$. In addition to these observations, JNK may play an important role in cardiomyocyte apoptosis (155). As such, JNK activation has been showed to cause increased cardiomyocyte apoptosis as early as at day 3 and 7 in a type 1 diabetic rodent model (155). Collectively, activation of both MAPK and JNK signaling seems to significantly contribute to the development of DC.

AMP-activated protein kinase (AMPK) activation. AMPK is a serine/threonine kinase that can detect cellular energy status and regulate energy homeostasis (156). Activation of AMPK is involved in multiple cellular processes such as autophagy (157). Activation of AMPK has been shown to inhibit mTOR, which is a protein kinase that regulates autophagy (158). A previous study showed that high glucose inhibited autophagic activity and the AMPK pathway in 


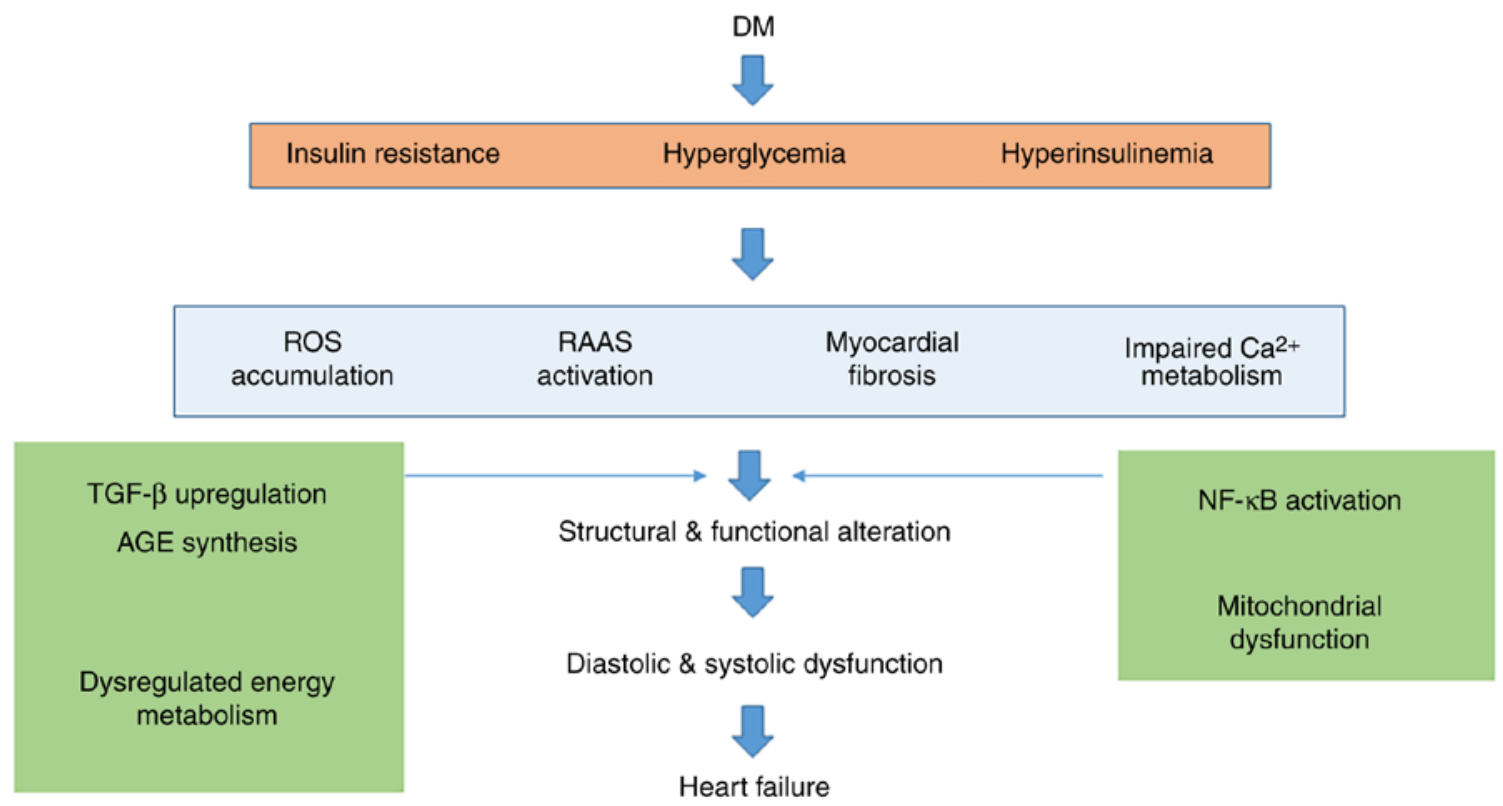

Figure 1. Overview of the mechanisms leading to heart failure in diabetic cardiomyopathy. DM, diabetes mellitus; ROS, reactive oxygen species; RAAS, renin-angiotensin-aldosterone system; TGF- $\beta$, transforming growth factor- $\beta$; AGE, advanced glycation end products; NF- $\kappa \mathrm{B}$, nuclear factor $\kappa \mathrm{B}$.

a DC cell model, thereby stimulating the interaction of beclin 1 (BECN1) and the anti-apoptotic protein BCL2 (159). Activation of AMPK results in phosphorylation of MAPK8, which in turn drives BCL2 phosphorylation and dissociates from the BECN1-BCL2 complex (15). Thus, AMPK restores cardiomyocyte autophagy through BCL2, preventing cardiomyocyte apoptosis. Dissociation of BCL2 from BECN1 via activation of MAPK8-BCL2 signaling may restore autophagy by driving AMPK activation and is important for the prevention of DC processes (160).

MicroRNAs. DC is associated with the dysregulated expression of miRNAs, short single-stranded noncoding RNAs of 20 nucleotides in length (161). Importantly, miRNAs bind to the 3'-untranslated region (3'UTR) of the mRNAs of target genes. Therefore miRNAs can participate in the regulation of multiple events in the pathogenesis and progression of DC, such as mitochondrial function, $\mathrm{Ca}^{2+}$ handling, ROS production, apoptosis, autophagy and fibrosis $(162,163)$. miR-15a, miR-21, miR-24, miR-29, miR-30d, miR-103, miR-126, miR-146a, miR-150, miR-191, miR-223, miR-320, miR-375 and miR-486 have all been reported to be overexpressed in type 2 diabetic patients (163-168). miR-103, miR-107, miR-143 and miR-181 play essential roles in the regulation of cellular insulin sensitivity and glucose metabolism $(163,169)$. High expression levels of miR-454, miR-500, miR-142-3p/5p and miR-1246 have been found in the circulating blood of patients with cardiac diastolic dysfunction (170). Other microRNAs, such as miR-113a, miR-133a and miR-150, have been reported to be related to cardiomyocyte hypertrophy and interstitial fibrosis (171).

\section{Treatment of diabetic cardiomyopathy}

At present, the therapeutic strategies for DC are still based on drug treatment. The principles include primarily acting against the pathogenesis of DC, and delaying the development of heart failure (172). Controlling blood sugar is fundamental for effectively reducing the cardiovascular morbidity of diabetes. Diet control and regular exercise are necessary for disease treatment. Clinical studies have found that the use of hypoglycemic agents to control blood glucose in patients with early stages of myocardial dysfunction can effectively delay the progression of cardiomyopathy in diabetic patients (173). Studies have confirmed that the use of metformin in diabetic patients can effectively reduce the mortality (174).

Most diabetic patients have hyperlipidemia in the early stage of the disease. Clinical studies have shown that statins and fibrates can effectively reduce the blood lipid levels and the mortality of cardiovascular disease in diabetic patients $(175,176)$. A large amount of ROS produced by oxidative stress can directly damage myocardial cells and vascular endothelial cells, causing myocardial dysfunction (177). A variety of antioxidant drugs such as vitamin $\mathrm{E}$ and angiotensin-converting enzyme inhibitors (ACEIs) can reduce the levels of ROS in the blood and therefore protect the myocardium (178). For DC patients with symptoms of heart failure, beta blockers have been shown to have a significant effect on improving ventricular function (179). Sharma and McNeill (180) tested the inhibitory effect of metoprolol on DC in animal models and found that metoprolol reduced fatty acid oxidation and improved ventricular function. Increased levels of angiotensin 2 in myocardial tissue, leading to increased aldosterone secretion, enhanced the content of ROS and led to myocardial cell damage and apoptosis (181).

In recent years, physical therapy has also been gradually applied to the treatment of diabetic complications. Studies have shown that hyperbaric oxygen therapy can reduce the fasting blood glucose by at least $20 \%$ in patients with type 2 diabetes, and reduce insulin resistance in obese diabetic patients (182). 
On the other hand, hyperbaric oxygen was found to reduce myocardial cell damage in DC rats (183). These studies indicate that hyperbaric oxygen therapy has considerable promise in the treatment of cardiovascular disease and DC.

In addition, stem cell therapy is the future of disease treatment, and it has been proven to be effective in treating a variety of cardiovascular diseases. Although stem cell therapy has not been applied to clinical DC treatment to date, in vivo and in vitro research suggests that bone marrow mesenchymal stem cells can effectively promote the growth and differentiation of cardiomyocytes in DC rats and significantly improve cardiac function $(184,185)$. Neel and Singla (186) found that induced pluripotent stem cells can effectively inhibit cardiomyocyte apoptosis and fibrosis in DC rats, and significantly improve the cardiac function of model animals. The protective effects of stem cells on the cardiovascular system in the DC model indicate that it has broad prospects in the treatment of DC.

Although the current treatments have largely improved the short-term prognosis of patients with diabetic cardiomyopathy, there are still no convincing or effective prevention strategies to avoid repeated and prolonged rehospitalization. The main challenges remain in the complexity of the pathogenesis of DC and the inefficiency of diagnostic approaches. Future studies need to focus on the improvement in diagnosis by coupling different diagnostic approaches. Advances in next generation sequencing and imaging technologies may help overcome these challenges.

\section{Conclusions}

$\mathrm{DC}$ is a major complication of diabetes that requires further elucidation. DC is closely correlated with cardiac mortality and morbidity. Echocardiography is currently the most commonly used diagnostic method for DC diagnosis. Novel modalities including MRI, PET and multiple serum/plasma biomarkers are emerging. However, the present methods have their limits, and therefore a combination of multiple methods should be recommended for the diagnosis of DC. The pathophysiology and pathogenesis of DC have not been fully elucidated. The presently proposed hypothesis (Fig. 1) includes hyperglycemia-associated metabolic and oxidative stress, lipotoxicity and hyperinsulinemia, and the treatment of DC is still based on drug therapy. The principles are mainly aimed at the pathogenesis of DC, and delay of the development of heart failure. Controlling blood sugar is fundamental for effectively reducing the cardiovascular morbidity of diabetes. Diet control and regular exercise are necessary for disease treatment. New therapeutic approaches covering cell-based or gene-based therapies are currently being investigated. Further research is required for understanding the mechanisms involved in the development of DC to enhance the discovery of clinically effective targets for preventing this condition and its progression to heart failure. We apologize to those authors for whom we did not cite their valuable works due to the large number of papers to be cited.

\section{Acknowledgements}

Not applicable.

\section{Funding}

No funding was received.

\section{Availability of data and materials}

Not applicable.

\section{Authors' contributions}

LS, GW and XG participated in the study design. GW, MY, TZ, SZ and GH participated in the preparation of the manuscript. LS, TZ and GW wrote and edited the manuscript. GW and $X G$ revised the manuscript and supervised the study. All authors read and approved the final manuscript.

\section{Ethics approval and consent to participate}

Not applicable.

\section{Patient consent for publication}

Not applicable.

\section{Competing interests}

The authors declare that they have no competing interests.

\section{References}

1. Lloyd-Jones D, Adams RJ, Brown TM, Carnethon M, Dai S, De Simone G, Ferguson TB, Ford E, Furie K, Gillespie C, et al: Executive summary: Heart disease and stroke statistics-2010 update: A report from the American heart association. Circulation 121: 948-954, 2010.

2. Boyle JP, Thompson TJ, Gregg EW, Barker LE and Williamson DF: Projection of the year 2050 burden of diabetes in the US adult population: Dynamic modeling of incidence, mortality, and prediabetes prevalence. Popul Health Metr 8: 29, 2010.

3. Regensteiner JG, Golden S, Huebschmann AG, Barrett-Connor E, Chang AY, Chyun D, Fox CS, Kim C, Mehta N, Reckelhoff JF, et al: Sex differences in the cardiovascular consequences of diabetes mellitus: A scientific statement from the American heart association. Circulation 132: 2424-2447, 2015.

4. Rubler S, Dlugash J, Yuceoglu YZ, Kumral T, Branwood AW and Grishman A: New type of cardiomyopathy associated with diabetic glomerulosclerosis. Am J Cardiol 30: 595-602, 1972.

5. Authors/Task Force Members, Rydén L, Grant PJ, Anker SD, Berne C, Cosentino F, Danchin N, Deaton C, Escaned J, Hammes HP, et al: ESC Guidelines on diabetes, pre-diabetes, and cardiovascular diseases developed in collaboration with the EASD: The Task Force on diabetes, pre-diabetes, and cardiovascular diseases of the European Society of Cardiology (ESC) and developed in collaboration with the European Association for the Study of Diabetes (EASD). Eur Heart J 34: 3035-3087, 2013.

6. Yancy CW, Jessup M, Bozkurt B, Butler J, Casey DE Jr, Drazner MH, Fonarow GC, Geraci SA, Horwich T, Januzzi JL, et al: 2013 ACCF/AHA guideline for the management of heart failure: A report of the American college of cardiology foundation/American heart association task force on practice guidelines. J Am Coll Cardiol 62: e147-e239, 2013.

7. Jia G, Whaley-Connell A and Sowers JR: Diabetic cardiomyopathy: A hyperglycaemia- and insulin-resistance-induced heart disease. Diabetologia 61: 21-28, 2018.

8. Redfield MM, Jacobsen SJ, Burnett JC Jr, Mahoney DW, Bailey KR and Rodeheffer RJ: Burden of systolic and diastolic ventricular dysfunction in the community: Appreciating the scope of the heart failure epidemic. JAMA 289: 194-202, 2003. 
9. Miki T, Yuda S, Kouzu H and Miura T: Diabetic cardiomyopathy: Pathophysiology and clinical features. Heart Fail Rev 18: 149-166, 2013.

10. Wang J, Song Y, Wang Q, Kralik PM and Epstein PN: Causes and characteristics of diabetic cardiomyopathy. Rev Diabet Stud 3: 108-117, 2006

11. Pappachan JM,Varughese GI,Sriraman R and Arunagirinathan G: Diabetic cardiomyopathy: Pathophysiology, diagnostic evaluation and management. World J Diabetes 4: 177-189, 2013.

12. Ghosh N and Katare R: Molecular mechanism of diabetic cardiomyopathy and modulation of microRNA function by synthetic oligonucleotides. Cardiovasc Diabetol 17: 43, 2018.

13. Varma U, Koutsifeli P, Benson VL, Mellor KM and Delbridge LMD: Molecular mechanisms of cardiac pathology in diabetes-Experimental insights. Biochim Biophys Acta Mol Basis Dis 1864: 1949-1959, 2018.

14. Kang Y, Wang S, Huang J, Cai L and Keller BB: Right ventricular dysfunction and remodeling in diabetic cardiomyopathy. Am J Physiol Heart Circ Physiol 316: H113-H122, 2019.

15. Tarquini R, Pala L, Brancati S, De Cosmo S, Mazzoccoli G and Rotella CM: Clinical approach to diabetic cardiomyopathy: A review of human studies. Curr Med Chem 25: 1510-1524, 2018.

16. Gao S, Ho D, Vatner DE and Vatner SF: Echocardiography in mice. Curr Protoc Mouse Biol 1: 71-83, 2011.

17. Qian C, Gong L, Yang Z, Chen W, Chen Y, Xu Z, Wu B, Tang C, Gao F and Zeng W: Diastolic dysfunction in spontaneous type 2 diabetes rhesus monkeys: A study using echocardiography and magnetic resonance imaging. BMC Cardiovasc Disord 15: 59, 2015.

18. Caglar Acar O, Epcacan S, Uner A, Ece I and Dogan M: Evaluation of left and right ventricular functions using conventional and tissue Doppler echocardiography in children with type 1 diabetes mellitus. J Pediatr Endocrinol Metab 29: 885-891, 2016.

19. Danzmann LC, Bodanese LC, Köhler I and Torres MR: Left atrioventricular remodeling in the assessment of the left ventricle diastolic function in patients with heart failure: A review of the currently studied echocardiographic variables. Cardiovasc Ultrasound 6: 56, 2008

20. Yu CM, Sanderson JE, Marwick TH and Oh JK: Tissue Doppler imaging a new prognosticator for cardiovascular diseases. J Am Coll Cardiol 49: 1903-1914, 2007.

21. Malm S, Frigstad S, Sagberg E, Larsson H and Skjaerpe T: Accurate and reproducible measurement of left ventricular volume and ejection fraction by contrast echocardiography: A comparison with magnetic resonance imaging. J Am Coll Cardiol 44: 1030-1035, 2004

22. Cosyns B, Droogmans S, Hernot S, Degaillier C, Garbar C Weytjens C, Roosens B, Schoors D, Lahoutte T, Franken PR and Van Camp G: Effect of streptozotocin-induced diabetes on myocardial blood flow reserve assessed by myocardial contrast echocardiography in rats. Cardiovasc Diabetol 7: 26, 2008.

23. Wang D, Xu JZ, Chen X, Xu TY, Zhang W, Li Y and Wang JG: Left atrial myocardial dysfunction in patients with primary aldosteronism as assessed by speckle-tracking echocardiography. J hypertension: May 30, 2019 (Epub ahead of print).

24. Cameli M, Mondillo S, Galderisi M, Mandoli GE, Ballo P, Nistri S, Capo V, D'Ascenzi F, D'Andrea A, Esposito R, et al Speckle tracking echocardiography: A practical guide. G Ital Cardiol (Rome) 18: 253-269, 2017 (In Italian).

25. Enomoto M, Ishizu T, Seo Y, Kameda Y, Suzuki H, Shimano H, Kawakami Y and Aonuma K: Myocardial dysfunction identified by three-dimensional speckle tracking echocardiography in type 2 diabetes patients relates to complications of microangiopathy. J Cardiol 68: 282-287, 2016.

26. Fang ZY, Schull-Meade R, Leano R, Mottram PM, Prins JB and Marwick TH: Screening for heart disease in diabetic subjects. Am Heart J 149: 349-354, 2005.

27. Rijzewijk LJ, van der Meer RW, Smit JW, Diamant M, Bax JJ, Hammer S, Romijn JA, de Roos A and Lamb HJ: Myocardial steatosis is an independent predictor of diastolic dysfunction in type 2 diabetes mellitus. J Am Coll Cardiol 52: 1793-1799, 2008.

28. Kwong RY and Korlakunta H: Diagnostic and prognostic value of cardiac magnetic resonance imaging in assessing myocardial viability. Top Magn Reson Imaging 19: 15-24, 2008

29. Sorrell VL and Reeves WC: Noninvasive right and left heart catheterization: Taking the echo lab beyond an image-only laboratory. Echocardiography 18: 31-41, 2001

30. Grady RM, Eisenberg PR and Bridges ND: Rational approach to use of heparin during cardiac catheterization in children. J Am Coll Cardiol 25: 725-729, 1995.
31. Kindermann M: How to diagnose diastolic heart failure: A consensus statement on the diagnosis of heart failure with normal left ventricular ejection fraction by the heart failure and echocardiography associations of the European society of cardiology. Eur Heart J 28: 2686-2687, 2007.

32. Yang FB, Guo WL, Sheng M, Sun L, Ding YY, Xu QQ, Xu MG and Lv HT: Diagnostic accuracy of coronary angiography using 64-slice computed tomography in coronary artery disease. Saudi Med J 36: 1156-1162, 2015.

33. Dharampal AS, Rossi A and de Feyter PJ: Computed tomography-coronary angiography in the detection of coronary artery disease. J Cardiovasc Med (Hagerstown) 12: 554-561, 2011.

34. Jiangping S, Zhe Z, Wei W, Yunhu S, Jie H, Hongyue W, Hong Z and Shengshou H: Assessment of coronary artery stenosis by coronary angiography: A head-to-head comparison with pathological coronary artery anatomy. Circ Cardiovasc Interv 6: 262-268, 2013.

35. Dinh W, Bansemir L, Füth R, Nickl W, Stasch JP, Coll-Barroso M, Lapp H, Bufe A, Wolfertz J, Scheffold T and Lankisch M: Increased levels of laminin and collagen type VI may reflect early remodelling in patients with acute myocardial infarction. Acta Cardiol 64: 329-334, 2009.

36. D'Souza A, Howarth FC, Yanni J, Dobryznski H, Boyett MR, Adeghate E, Bidasee KR and Singh J: Left ventricle structural remodelling in the prediabetic Goto-Kakizaki rat. Exp Physiol 96: 875-888, 2011.

37. Chen LC, Shibu MA, Liu CJ, Han CK, Ju DT, Chen PY, Viswanadha VP, Lai CH, Kuo WW and Huang CY: ERK1/2 mediates the lipopolysaccharide-induced upregulation of FGF-2, uPA, MMP-2, MMP-9 and cellular migration in cardiac fibroblasts. Chem Biol Interact 306: 62-69, 2019.

38. DeLeon-Pennell KY, Meschiari CA, Jung M and Lindsey ML: Matrix metalloproteinases in myocardial infarction and heart failure. Prog Mol Biol Transl Sci 147: 75-100, 2017.

39. Radosinska J, Barancik M and Vrbjar N: Heart failure and role of circulating MMP-2 and MMP-9. Panminerva Med 59: 241-253, 2017.

40. Tanaka K, Essick EE, Doros G, Tanriverdi K, Connors LH, Seldin DC and Sam F: Circulating matrix metalloproteinases and tissue inhibitors of metalloproteinases in cardiac amyloidosis. J Am Heart Assoc 2: e005868, 2013.

41. Ban CR, Twigg SM, Franjic B, Brooks BA, Celermajer D, Yue DK and McLennan SV: Serum MMP-7 is increased in diabetic renal disease and diabetic diastolic dysfunction. Diabetes Res Clin Pract 87: 335-341, 2010.

42. Yeh JK, Chen CC, Hsieh MJ, Tsai ML, Yang CH, Chen DY, Chang SH, Wang CY, Lee CH and Hsieh IC: Impact of homocysteine level on long-term cardiovascular outcomes in patients after coronary artery stenting. J Atheroscler Thromb 24: 696-705, 2017.

43. Shargorodsky M, Boaz M, Pasternak S, Hanah R, Matas Z, Fux A, Beigel Y and Mashavi M: Serum homocysteine, folate, vitamin B12 levels and arterial stiffness in diabetic patients: Which of them is really important in atherogenesis? Diabetes Metab Res Rev 25: 70-75, 2009.

44. Mishra PK, Tyagi N, Sen U, Joshua IG and Tyagi SC: Synergism in hyperhomocysteinemia and diabetes: Role of PPAR gamma and tempol. Cardiovasc Diabetol 9: 49, 2010.

45. Chavali V, Tyagi SC and Mishra PK: Predictors and prevention of diabetic cardiomyopathy. Diabetes Metab Syndr Obes 6: 151-160, 2013.

46. Hayden MR and Tyagi SC: Homocysteine and reactive oxygen species in metabolic syndrome, type 2 diabetes mellitus, and atheroscleropathy: The pleiotropic effects of folate supplementation. Nutr J 3: 4, 2004

47. Quilliot D, Alla F, Böhme P, Bruntz JF, Hammadi M, Dousset B, Ziegler $\mathrm{O}$ and Zannad F: Myocardial collagen turnover in normotensive obese patients: Relation to insulin resistance. Int J Obes (Lond) 29: 1321-1328, 2005.

48. Epshteyn V, Morrison K, Krishnaswamy P, Kazanegra R, Clopton P, Mudaliar S, Edelman S, Henry R and Maisel A: Utility of B-type natriuretic peptide (BNP) as a screen for left ventricular dysfunction in patients with diabetes. Diabetes Care 26: 2081-2087, 2003.

49. Russell NE, Higgins MF, Amaruso M, Foley M and McAuliffe FM: Troponin T and pro-B-type natriuretic Peptide in fetuses of type 1 diabetic mothers. Diabetes Care 32: 2050-2055, 2009.

50. Betti I, Castelli G, Barchielli A, Beligni C, Boscherini V, De Luca L, Messeri G, Gheorghiade M, Maisel A and Zuppiroli A: The role of N-terminal PRO-brain natriuretic peptide and echocardiography for screening asymptomatic left ventricular dysfunction in a population at high risk for heart failure. The PROBE-HF study. J Card Fail 15: 377-384, 2009. 
51. Chiu AP, Bierende D, Lal N, Wang F, Wan A, Vlodavsky I, Hussein B and Rodrigues B: Dual effects of hyperglycemia on endothelial cells and cardiomyocytes to enhance coronary LPL activity. Am J Physiol Heart Circ Physiol 314: H82-h94, 2018.

52. Poornima IG, Parikh P and Shannon RP: Diabetic cardiomyopathy: The search for a unifying hypothesis. Circ Res 98: 596-605, 2006.

53. Du X, Matsumura T, Edelstein D, Rossetti L, Zsengellér Z, Szabó $\mathrm{C}$ and Brownlee M: Inhibition of GAPDH activity by poly(ADP-ribose) polymerase activates three major pathways of hyperglycemic damage in endothelial cells. J Clin Invest 112 1049-1057, 2003.

54. Cai L, Li W, Wang G, Guo L, Jiang Y and Kang YJ Hyperglycemia-induced apoptosis in mouse myocardium: Mitochondrial cytochrome C-mediated caspase-3 activation pathway. Diabetes 51: 1938-1948, 2002.

55. Nishikawa T, Edelstein D, Du XL, Yamagishi S, Matsumura T, Kaneda Y, Yorek MA, Beebe D, Oates PJ, Hammes HP, et al: Normalizing mitochondrial superoxide production blocks three pathways of hyperglycaemic damage. Nature 404: 787-790, 2000

56. Mavrogiannaki AN and Migdalis IN: Nonalcoholic Fatty liver disease, diabetes mellitus and cardiovascular disease: Newer data. Int J Endocrinol 2013: 450639, 2013.

57. Mracek T, Gao D, Tzanavari T, Bao Y, Xiao X, Stocker C, Trayhurn P and Bing C: Downregulation of zinc-\{alpha\}2-glycoprotein in adipose tissue and liver of obese ob/ob mice and by tumour necrosis factor-alpha in adipocytes. J Endocrinol 204 $165-172,2010$

58. Wende AR and Abel ED: Lipotoxicity in the heart. Biochim Biophys Acta 1801: 311-319, 2010.

59. van de Weijer T, Schrauwen-Hinderling VB and Schrauwen $P$ : Lipotoxicity in type 2 diabetic cardiomyopathy. Cardiovasc Res 92: 10-18, 2011.

60. Raeis V, Philip-Couderc P, Roatti A, Habre W, Sierra J, Kalangos A, Beghetti M and Baertschi AJ: Central venous hypoxemia is a determinant of human atrial ATP-sensitive potassium channel expression: Evidence for a novel hypoxia-inducible factor 1alpha-Forkhead box class $\mathrm{O}$ signaling pathway. Hypertension 55: 1186-1192, 2010.

61. Ouwens DM, Diamant M, Fodor M, Habets DDJ, Pelsers MMAL, El Hasnaoui M, Dang ZC, van den Brom CE, Vlasblom R, Rietdijk A, et al: Cardiac contractile dysfunction in insulin-resistant rats fed a high-fat diet is associated with elevated CD36-mediated fatty acid uptake and esterification. Diabetologia 50: 1938-1948, 2007.

62. Ritchie RH, Love JE, Huynh K, Bernardo BC, Henstridge DC Kiriazis H, Tham YK, Sapra G, Qin C, Cemerlang N, et al: Enhanced phosphoinositide 3-kinase $(\mathrm{p} 110 \alpha)$ activity prevents diabetes-induced cardiomyopathy and superoxide generation in a mouse model of diabetes. Diabetologia 55: 3369-3381, 2012.

63. Durgan DJ, Moore MW, Ha NP, Egbejimi O, Fields A Mbawuike U,Egbejimi A, Shaw CA, Bray MS, Nannegari V, et al: Circadian rhythms in myocardial metabolism and contractile function: Influence of workload and oleate. Am J Physiol Heart Circ Physiol 293: H2385-H2393, 2007.

64. Harmancey R, Lam TN, Lubrano GM, Guthrie PH, Vela D and Taegtmeyer $\mathrm{H}$ : Insulin resistance improves metabolic and contractile efficiency in stressed rat heart. FASEB J 26: 3118-3126, 2012

65. Feng B, Chen S, Chiu J, George B and Chakrabarti S: Regulation of cardiomyocyte hypertrophy in diabetes at the transcriptional level. Am J Physiol Endocrinol Metab 294: E1119-E1126, 2008.

66. Yusuf J, Khan MU, Cheema Y, Bhattacharya SK and Weber KT: Disturbances in calcium metabolism and cardiomyocyte necrosis: Prog Cardiovasc Dis 55: 77-86, 2012.

67. Shamoo AE and Ambudkar IS: Regulation of calcium transport in cardiac cells. Can J Physiol Pharmacol 62: 9-22, 1984.

68. Barry WH and Bridge $\mathrm{JH}$ : Intracellular calcium homeostasis in cardiac myocytes. Circulation 87: 1806-1815, 1993.

69. Bigi MAB, Faramarzi H, Gaeini AA, Ravasi AA, Izadi MR, Delfan $M$ and Izadi E: Upregulation of ryanodine receptor calcium channels (RyR2) in rats with induced diabetes after 4 weeks of high intensity interval training. Int Cardiovasc Res J 10: $1-5,2016$.

70. Uthman L, Baartscheer A, Schumacher CA, Fiolet JWT, Kuschma MC, Hollmann MW, Coronel R, Weber NC and Zuurbier CJ: Direct cardiac actions of sodium glucose cotransporter 2 inhibitors target pathogenic mechanisms underlying heart failure in diabetic patients. Front Physiol 9: 1575, 2018.
71. Ghazi L and Drawz P: Advances in understanding the renin-angiotensin-aldosterone system (RAAS) in blood pressure control and recent pivotal trials of RAAS blockade in heart failure and diabetic nephropathy. F1000Res 6: pii: F1000 Faculty Rev-1297, 2017

72. Underwood PC and Adler GK: The renin angiotensin aldosterone system and insulin resistance in humans. Curr Hypertens Rep 15: 59-70, 2013.

73. Pacurari M, Kafoury R, Tchounwou PB and Ndebele K: The Renin-Angiotensin-aldosterone system in vascular inflammation and remodeling. Int J Inflam 2014: 689360, 2014.

74. Lim HS, MacFadyen RJ and Lip GY: Diabetes mellitus, the renin-angiotensin-aldosterone system, and the heart. Arch Intern Med 164: 1737-1748, 2004.

75. Cooper ME: The role of the renin-angiotensin-aldosterone system in diabetes and its vascular complications. Am J Hypertens 17: 16S-20S.A2-A4, 2004

76. Ohkura SI, Usui S, Takashima SI, Takuwa N, Yoshioka K, Okamoto Y, Inagaki Y, Sugimoto N, Kitano T, Takamura M, et al: Augmented sphingosine 1 phosphate receptor-1 signaling in cardiac fibroblasts induces cardiac hypertrophy and fibrosis through angiotensin II and interleukin-6. PLoS One 12: e0182329, 2017.

77. Bugger $\mathrm{H}$ and Abel ED: Molecular mechanisms of diabetic cardiomyopathy. Diabetologia 57: 660-671, 2014

78. Al Hroob AM, Abukhalil MH, Hussein OE and Mahmoud AM: Pathophysiological mechanisms of diabetic cardiomyopathy and the therapeutic potential of epigallocatechin-3-gallate. Biomed Pharmacother 109: 2155-2172, 2019.

79. Marwick TH, Ritchie R, Shaw JE and Kaye D: Implications of underlying mechanisms for the recognition and management of diabetic cardiomyopathy. J Am Coll Cardiol 71: 339-351, 2018.

80. Westermeier F, Riquelme JA, Pavez M, Garrido V, Díaz A, Verdejo HE, Castro PF, García L and Lavandero S: New molecular insights of insulin in diabetic cardiomyopathy. Front Physiol 7: 125, 2016

81. Nakamura H, Matoba S, Iwai-Kanai E, Kimata M, Hoshino A, Nakaoka M, Katamura M, Okawa Y, Ariyoshi M, Mita Y, et al: p53 promotes cardiac dysfunction in diabetic mellitus caused by excessive mitochondrial respiration-mediated reactive oxygen species generation and lipid accumulation. Circ Heart Fail 5: 106-115, 2012.

82. Limas C and Limas CJ: Reduced number of beta-adrenergic receptors in the myocardium of spontaneously hypertensive rats. Biochem Biophys Res Commun 83: 710-714, 1978.

83. Lorenz K, Rosner MR, Brand T and Schmitt JP: Raf kinase inhibitor protein: Lessons of a better way for $\beta$-adrenergic receptor activation in the heart. J Physiol 595: 4073-4087, 2017.

84. Wallukat G: The beta-adrenergic receptors. Herz 27: 683-690, 2002.

85. Xu Q, Dalic A, Fang L, Kiriazis H, Ritchie RH, Sim K, Gao XM, Drummond G, Sarwar M, Zhang YY, et al: Myocardial oxidative stress contributes to transgenic $\beta \square$-adrenoceptor activation-induced cardiomyopathy and heart failure. Br J Pharmacol 162: 1012-1028, 2011.

86. Day RT, Cavaglieri Rde C, Tabatabaimir H, Mantravadi V, Lee MJ, Barnes JL, Kasinath BS and Feliers D: Acute hyperglycemia rapidly stimulates VEGF mRNA translation in the kidney. Role of angiotensin type 2 receptor (AT2). Cell Signal 22: 1849-1857, 2010.

87. Ali MO: Pulmonary complications in diabetes mellitus. Mymensingh Med J 23: 603-605, 2014.

88. Pavlov VI, La Bonte LR, Baldwin WM, Markiewski MM, Lambris JD and Stahl GL: Absence of mannose-binding lectin prevents hyperglycemic cardiovascular complications. Am J Pathol 180: 104-112, 2012.

89. Tang M, Zhou F, Zhang W, Guo Z, Shang Y, Lu H, Lu R, Zhang Y, Chen Y and Zhong M: The role of thrombospondin-1-mediated TGF- $\beta 1$ on collagen type III synthesis induced by high glucose. Mol Cell Biochem 346: 49-56, 2011

90. Guo Y, Zhuang X, Huang Z, Zou J, Yang D, Hu X, Du Z, Wang $L$ and Liao $X$ : Klotho protects the heart from hyperglycemia-induced injury by inactivating ROS and NF- $\kappa$ B-mediated inflammation both in vitro and in vivo. Biochim Biophys Acta Mol Basis Dis 1864: 238-251, 2018.

91. Lee JM, Calkins MJ, Chan K, Kan YW and Johnson JA: Identification of the NF-E2-related factor-2-dependent genes conferring protection against oxidative stress in primary cortical astrocytes using oligonucleotide microarray analysis. J Biol Chem 278: 12029-12038, 2003. 
92. Kwak MK, Itoh K, Yamamoto M and Kensler TW: Enhanced expression of the transcription factor Nrf2 by cancer chemopreventive agents: Role of antioxidant response element-like sequences in the nrf2 promoter. Mol Cell Biol 22: 2883-2892, 2002.

93. Mercado N, Thimmulappa R, Thomas CM, Fenwick PS Chana KK, Donnelly LE, Biswal S, Ito K and Barnes PJ: Decreased histone deacetylase 2 impairs Nrf2 activation by oxidative stress. Biochem Biophys Res Commun 406: 292-298, 2011.

94. Yoh K, Hirayama A, Ishizaki K, Yamada A, Takeuchi M Yamagishi S, Morito N, Nakano T, Ojima M, Shimohata H, et al Hyperglycemia induces oxidative and nitrosative stress and increases renal functional impairment in Nrf2-deficient mice. Genes Cells 13: 1159-1170, 2008.

95. He X, Kan H, Cai L and Ma Q: Nrf2 is critical in defense against high glucose-induced oxidative damage in cardiomyocytes. J Mol Cell Cardiol 46: 47-58, 2009.

96. Cosso L, Maineri EP, Traverso N, Rosatto N, Pronzato MA Cottalasso D, Marinari UM and Odetti P: Induction of heme oxygenase 1 in liver of spontaneously diabetic rats. Free Radic Res 34: 189-191, 2001.

97. Shi S, Lei S, Tang C, Wang K and Xia Z: Melatonin attenuates acute kidney ischemia/reperfusion injury in diabetic rats by activation of the SIRT1/Nrf2/HO-1 signaling pathway. Biosci Rep 39: pii: BSR20181614, 2019.

98. Ye Z, Guo Q, Xia P, Wang N, Wang E and Yuan Y: Sevoflurane postconditioning involves an up-regulation of HIF- $1 \alpha$ and HO-1 expression via PI3K/Akt pathway in a rat model of focal cerebral ischemia. Brain Res 1463: 63-74, 2012.

99. Tsuchihashi S, Fondevila C and Kupiec-Weglinski JW: Heme oxygenase system in ischemia and reperfusion injury. Ann Transplant 9: 84-87, 2004.

100. Mallick IH, Winslet MC and Seifalian AM: Pyrrolidine dithiocarbamate protects the small bowel from warm ischaemia/reperfusion injury of the intestine: The role of haem oxygenase. Clin Sci (Lond) 111: 373-380, 2006.

101. Chen YH, Yet SF and Perrella MA: Role of heme oxygenase-1 in the regulation of blood pressure and cardiac function. Exp Biol Med (Maywood) 228: 447-453, 2003.

102. Bai CH, Chen JR, Chiu HC, Chou CC, Chau LY and Pan WH: Shorter GT repeat polymorphism in the heme oxygenase-1 gene promoter has protective effect on ischemic stroke in dyslipidemia patients. J Biomed Sci 17: 12, 2010.

103. Nieto MA, Huang RY, Jackson RA and Thiery JP: EMT: 2016 Cell 166: 21-45, 2016.

104. Kong P, Christia P and Frangogiannis NG: The pathogenesis of cardiac fibrosis. Cell Mol Life Sci 71: 549-574, 2014.

105. García R, Nistal JF, Merino D, Price NL, Fernández-Hernando C Beaumont J, González A, Hurlé MA and Villar AV: p-SMAD2/3 and DICER promote pre-miR-21 processing during pressure overload-associated myocardial remodeling. Biochim Biophys Acta 1852: 1520-1530, 2015

106. Niu L,Cui X,Qi Y,XieD,WuQ,ChenX,Ge J and Liu Z: Involvement of TGF- $31 / \mathrm{Smad} 3$ signaling in carbon tetrachloride-induced acute liver injury in mice. PLoS One 11: e0156090, 2016.

107. Li TT, Si GM and Chen FC: Effects of Shenqi Jiedu Decoction on expressions of transforming growth factor-beta1, smad 2 and $\operatorname{smad} 3$ in renal tissues of rats with chronic renal failure induced by adenine Zhong Xi Yi Jie He Xue Bao 8: 263-268, 2010 (In Chinese).

108. Nelson EF, Huang CW, Ewel JM, Chang AA and Yuan C: Halofuginone down-regulates Smad3 expression and inhibits the TGFbeta-induced expression of fibrotic markers in human corneal fibroblasts. Mol Vis 18: 479-487, 2012.

109. Dong C, Mi R, Jin G, Zhou Y, Zhang J and Liu F: Identification of the proliferative effect of Smad 2 and 3 in the TGF $\beta 2 / \mathrm{Smad}$ signaling pathway using RNA interference in a glioma cell line. Mol Med Rep 12: 1824-1828, 2015.

110. Piek E, Wen JJ, Heyer J, Escalante-Alcalde D, Stewart CL, Weinstein M, Deng C, Kucherlapati R, Bottinger EP and Roberts AB: Functional characterization of transforming growth factor beta signaling in Smad2- and Smad3-deficien fibroblasts. J Biol Chem 276: 19945-19953, 2001.

111. Feng XH, Liang YY, Liang M, Zhai W and Lin X: Direct interaction of c-Myc with Smad2 and Smad3 to inhibit TGF-beta-mediated induction of the CDK inhibitor p15(Ink4B). Mol Cell 9: 133-143, 2002

112. Li P, Oparil S, Novak L, Cao X, Shi W, Lucas J and Chen YF: ANP signaling inhibits TGF-beta-induced Smad2 and Smad3 nuclear translocation and extracellular matrix expression in rat pulmonary arterial smooth muscle cells. J Appl Physiol (1985) 102: 390-398, 2007
113. Divakaran V, Adrogue J, Ishiyama M, Entman ML, Haudek S, Sivasubramanian N and Mann DL: Adaptive and maladptive effects of SMAD3 signaling in the adult heart after hemodynamic pressure overloading. Circ Heart Fail 2: 633-642, 2009.

114. Van der Heiden K, Cuhlmann S, Luong le A, Zakkar M and Evans PC: Role of nuclear factor kappaB in cardiovascular health and disease. Clin Sci (Lond) 118: 593-605, 2010

115. Hink U, Tsilimingas N, Wendt $M$ and Munzel T: Mechanisms underlying endothelial dysfunction in diabetes mellitus: Therapeutic implications. Treat Endocrinol 2: 293-304, 2003.

116. Sugiyama S, Miyata T, Ueda Y, Tanaka H, Maeda K, Kawashima S, Van Ypersele de Strihou C and Kurokawa K Plasma levels of pentosidine in diabetic patients: An advanced glycation end product. J Am Soc Nephrol 9: 1681-1688, 1998.

117. Kanauchi M, Tsujimoto $\mathrm{N}$ and Hashimoto T: Advanced glycation end products in nondiabetic patients with coronary artery disease. Diabetes Care 24: 1620-1623, 2001.

118. Hussain F, Sheikh MA, Maan MA and Jamil A: Advanced glycation end products (AGEs) in diabetic patients with systemic lupus erythematosus. Int J Agric Biol 14: 440-444, 2012.

119. Choi EY, Kwon HM, Ahn CW, Lee GT, Joung B, Hong BK, Yoon YW, Kim D, Byun KH, Kang TS, et al: Serum levels of advanced glycation end products are associated with in-stent restenosis in diabetic patients. Yonsei Med J 46: 78-85, 2005

120. Khalifah RG, Todd P, Booth AA, Yang SX, Mott JD and Hudson BG: Kinetics of nonenzymatic glycation of ribonuclease A leading to advanced glycation end products. Paradoxical inhibition by ribose leads to facile isolation of protein intermediate for rapid post-Amadori studies. Biochemistry 35: 4645-4654, 1996.

121. Vlassara H: Advanced glycation end-products and atherosclerosis. Ann Med 28: 419-426, 1996.

122. Peppa $\mathrm{M}$ and Vlassara $\mathrm{H}$ : Advanced glycation end products and diabetic complications: A general overview. Hormones (Athens) 4: 28-37, 2005.

123. Nożyński J, Zakliczyński M, Konecka-Mrowka D, Zielinska T, Zakliczynska H, Nikiel B, Mlynarczyk-Liszka J, Mrowka A, Zembala-Nozynska E, Pijet M, et al: Advanced glycation end product accumulation in the cardiomyocytes of heart failure patients with and without diabetes. Ann Transplant 17: 53-61, 2012.

124. Grzebyk E, Knapik-Kordecka M and Piwowar A: Advanced glycation end-products and cathepsin cysteine protease in type 2 diabetic patients. Pol Arch Med Wewn 123: 364-370, 2013.

125. Kuwajima S: Immunochemical determination of advanced glycation end products in erythrocyte peripheral-membrane proteins from diabetic patients. Hokkaido Igaku Zasshi 68: 695-704, 1993 (In Japanese).

126. Low H, Hoang A, Forbes J, Thomas M, Lyons JG, Nestel P, Bach LA and Sviridov D: Advanced glycation end-products (AGEs) and functionality of reverse cholesterol transport in patients with type 2 diabetes and in mouse models. Diabetologia 55: 2513-2521, 2012.

127. Singh VP, Bali A, Singh N and Jaggi AS: Advanced glycation end products and diabetic complications. Korean J Physiol Pharmacol 18: 1-14, 2014.

128. Feng Y, Zhao H, Xu X, Buys ES, Raher MJ, Bopassa JC, Thibault H, Scherrer-Crosbie M, Schmidt U and Chao W: Innate immune adaptor MyD88 mediates neutrophil recruitment and myocardial injury after ischemia-reperfusion in mice. Am J Physiol Heart Circ Physiol 295: H1311-H1318, 2008.

129. Weber NC, Toma O, Wolter JI, Obal D, Müllenheim J, Preckel B and Schlack W: The noble gas xenon induces pharmacological preconditioning in the rat heart in vivo via induction of PKC-epsilon and p38 MAPK. Br J Pharmacol 144: 123-132, 2005.

130. Das Evcimen N and King GL: The role of protein kinase C activation and the vascular complications of diabetes. Pharmacol Res 55: 498-510, 2007.

131. Koya D and King GL: Protein kinase $C$ activation and the development of diabetic complications. Diabetes 47: 859-866, 1998.

132. Nogueira-Machado JA and Bosco AA: PKC inhibition and diabetic complications. Recent Patents End Metab Immune Drug Discov 2: 72-78, 2008.

133. Ishii H, Koya D and King GL: Protein kinase $C$ activation and its role in the development of vascular complications in diabetes mellitus. J Mol Med (Berl) 76: 21-31, 1998.

134. Shen GX: Selective protein kinase C inhibitors and their applications. Curr Drug Targets Cardiovasc Haematol Disord 3 301-307, 2003 
135. Bursell SE and King GL: Can protein kinase C inhibition and vitamin $\mathrm{E}$ prevent the development of diabetic vascular complications? Diabetes Res Clin Pract 45: 169-182, 1999.

136. Jia G, DeMarco VG and Sowers JR: Insulin resistance and hyperinsulinaemia in diabetic cardiomyopathy. Nat Rev Endocrinol 12: 144-153, 2016.

137. Lee TI, Kao YH, Chen YC, Huang JH, Hsiao FC and Chen YJ: Peroxisome proliferator-activated receptors modulate cardiac dysfunction in diabetic cardiomyopathy. Diabetes Res Clin Pract 100: 330-339, 2013.

138. Finck BN, Lehman JJ, Leone TC, Welch MJ, Bennett MJ, Kovacs A, Han X, Gross RW, Kozak R, Lopaschuk GD and Kelly DP: The cardiac phenotype induced by PPARalpha overexpression mimics that caused by diabetes mellitus. J Clin Invest 109: 121-130, 2002.

139. Leone TC, Weinheimer CJ and Kelly DP: A critical role for the peroxisome proliferator-activated receptor alpha (PPARalpha) in the cellular fasting response: The PPARalpha-null mouse as a model of fatty acid oxidation disorders. Proc Natl Acad Sci USA 96: 7473-7478, 1999.

140. Pedraza N, Rosell M, Villarroya J, Iglesias R, Gonzalez FJ, Solanes G and Villarroya F: Developmental and tissue-specific involvement of peroxisome proliferator-activated receptor-alpha in the control of mouse uncoupling protein-3 gene expression. Endocrinology 147: 4695-4704, 2006.

141. Zhou YT, Grayburn P, Karim A, Shimabukuro M, Higa M, Baetens D, Orci L and Unger RH: Lipotoxic heart disease in obese rats: Implications for human obesity. Proc Natl Acad Sci USA 97: 1784-1789, 2000.

142. Anderson EJ, Kypson AP, Rodriguez E, Anderson CA, Lehr EJ and Neufer PD: Substrate-specific derangements in mitochondrial metabolism and redox balance in the atrium of the type 2 diabetic human heart. J Am Coll Cardiol 54: 1891-1898, 2009.

143. Razeghi P, Young ME, Cockrill TC, Frazier OH and Taegtmeyer H: Downregulation of myocardial myocyte enhancer factor $2 \mathrm{C}$ and myocyte enhancer factor $2 \mathrm{C}$-regulated gene expression in diabetic patients with nonischemic heart failure. Circulation 106: 407-411, 2002

144. Cheng L, Ding G, Qin Q, Huang Y, Lewis W, He N, Evans RM, Schneider MD, BrakoFA, Xiao Y, et al: Cardiomyocyte-restricted peroxisome proliferator-activated receptor-delta deletion perturbs myocardial fatty acid oxidation and leads to cardiomyopathy. Nat Med 10: 1245-1250, 2004

145. Scirpo R, Fiorotto R, Villani A, Fabris L and Strazzabosco M Stimulation of Nuclear Receptor PPAR- $\gamma$ Limits NF-kB-dependent inflammation in cystic fibrosis biliary epithelium. Dig Liver Dis 47: e43-e44, 2015.

146. Ng DC, Long CS and Bogoyevitch MA: A role for the extracellular signal-regulated kinase and p38 mitogen-activated protein kinases in Interleukin-1beta-stimulated delayed signal tranducer and activator of transcription 3 activation, atrial natriuretic factor expression and cardiac myocyte morphology. J Biol Chem 276 29490-29498, 2001

147. Lei Y, Xu Q, Zeng B, Zhang W, Zhen Y, Zhai Y, Cheng F, Mei W, Zheng D, Feng J, et al: Angiotensin-(1-7) protects cardiomyocytes against high glucose-induced injuries through inhibiting reactive oxygen species-activated leptin-p38 mitogen-activated protein kinase/extracellular signal-regulated protein kinase $1 / 2$ pathways but not leptin-c-Jun N-terminal kinase pathway in vitro. J Diabetes Investig 8: 434-445, 2016.

148. Bo B, Tang J, Liu H, Chen J, Li Y and Song W: Apelin-13 induces ERK1/2 but not 338 MAPK activation through coupling of the human apelin receptor to the Gi2 pathway. Acta Biochim Biophys Sin (Shanghai) 40: 311-318, 2008

149. Kiribayashi K, Masaki T, Naito T, Ogawa T, Ito T, Yorioka N and Kohno N: Angiotensin II induces fibronectin expression in human peritoneal mesothelial cells via ERK1/2 and p38 MAPK. Kidney Int 67: 1126-1135, 2005.

150. Blanc A, Pandey NR and Srivastava AK: Synchronous activation of ERK 1/2, p38mapk and PKB/Akt signaling by $\mathrm{H} 2 \mathrm{O} 2$ in vascular smooth muscle cells: Potential involvement in vascular disease (review). Int J Mol Med 11: 229-234, 2003.

151. Strniskova M, Barancik M, Neckar J and Ravingerova T: Mitogen-activated protein kinases in the acute diabetic myocardium. Mol Cell Biochem 249: 59-65, 2003.

152. Jia G, Habibi J, DeMarco VG, Martinez-Lemus LA, Ma L, Whaley-Connell AT, Aroor AR, Domeier TL, Zhu Y, Meininger GA, et al: Endothelial mineralocorticoid receptor deletion prevents diet-induced cardiac diastolic dysfunction in females. Hypertension 66: 1159-1167, 2015.
153. Rouf R, MacFarlane EG, Takimoto E, Chaudhary R, Nagpal V, Rainer PP, Bindman JG, Gerber EE, Bedja D, Schiefer C, et al: Nonmyocyte ERK1/2 signaling contributes to load-induced cardiomyopathy in Marfan mice. JCI Insight 2: pii: 91588 , 2017

154. Wang Y, Zhou S, Sun W, McClung K, Pan Y, Liang G, Tan Y, Zhao Y, Liu Q, Sun J and Cai L: Inhibition of JNK by novel curcumin analog C66 prevents diabetic cardiomyopathy with a preservation of cardiac metallothionein expression. Am J Physiol Endocrinol Metab 306: E1239-E1247, 2014.

155. Gurusamy N, Watanabe K, Ma M, Zhang S, Muslin AJ, Kodama $M$ and Aizawa Y: Dominant negative 14-3-3 promotes cardiomyocyte apoptosis in early stage of type I diabetes mellitus through activation of JNK. Biochem Biophys Res Commun 320: 773-780, 2004

156. Hardie DG: AMP-activated/SNF1 protein kinases: Conserved guardians of cellular energy. Nat Rev Mol Cell Biol 8: 774-785, 2007.

157. Herzig S and Shaw RJ: AMPK: Guardian of metabolism and mitochondrial homeostasis. Nat Rev Mol Cell Biol 19: 121-135, 2018.

158. Shaw RJ: LKB1 and AMP-activated protein kinase control of mTOR signalling and growth. Acta Physiol (Oxf) 196: 65-80, 2009.

159. Xu K, Liu XF, Ke ZQ, Yao Q, Guo S and Liu C: Resveratrol modulates apoptosis and autophagy induced by high glucose and palmitate in cardiac cells. Cell Physiol Biochem 46: 2031-2040, 2018.

160. Jweied EE, Mckinney RD, Walker LA, Brodsky I, Geha AS, Massad MG, Buttrick PM and de Tombe PP: Depressed cardiac myofilament function in human diabetes mellitus. Am J Physiol Heart Circ Physiol 289: H2478-H2483, 2005.

161. Khullar M, Cheema BS and Raut SK: Emerging evidence of epigenetic modifications in vascular complication of diabetes. Front Endocrinol (Lausanne) 8: 237, 2017.

162. Barwari T, Joshi A and Mayr M: MicroRNAs in cardiovascular disease. J Am Coll Cardiol 68: 2577-2584, 2016.

163. Zampetaki A, Kiechl S, Drozdov I, Willeit P, Mayr U, Prokopi M, Mayr A, Weger S, Oberhollenzer F, Bonora E, et al: Plasma microRNA profiling reveals loss of endothelial miR-126 and other microRNAs in type 2 diabetes. Circ Res 107: 810-817, 2010.

164. Chen Q, Qiu F, Zhou K, Matlock HG, Takahashi Y, Rajala RVS, Yang Y, Moran E and Ma JX: Pathogenic Role of microRNA-21 in Diabetic Retinopathy Through Downregulation of PPAR $\alpha$. Diabetes 66: 1671-1682, 2017.

165. Rawal S, Munasinghe PE, Nagesh PT, Lew JKS, Jones GT, Williams MJA, Davis P, Bunton D, Galvin IF, Manning P, et al: Down-regulation of miR-15a/b accelerates fibrotic remodelling in the Type 2 diabetic human and mouse heart. Clin Sci (Lond) 131: 847-863, 2017.

166. Assmann TS, Recamonde-Mendoza M, De Souza BM and Crispim D: MicroRNA expression profiles and type 1 diabetes mellitus: Systematic review and bioinformatic analysis. Endocr Connect 6: 773-790, 2017.

167. Demirsoy IH, Ertural DY, Balci S, Çınkır Ü, Sezer K, Tamer L and Aras N: Profiles of circulating MiRNAs following metformin treatment in patients with type 2 diabetes. J Med Biochem 37: 499-506, 2018.

168. Prabu P, Rome S, Sathishkumar C, Gastebois C, Meugnier E, Mohan V and Balasubramanyam M: MicroRNAs from urinary extracellular vesicles are non-invasive early biomarkers of diabetic nephropathy in type 2 diabetes patients with the 'Asian Indian phenotype'. Diabetes Metab 45: 276-285, 2019.

169. Trajkovski M, Hausser J, Soutschek J, Bhat B, Akin A Zavolan M, Heim MH and Stoffel M: MicroRNAs 103 and 107 regulate insulin sensitivity. Nature 474: 649-653, 2011.

170. Nair N, Kumar S, Gongora E and Gupta S: Circulating miRNA as novel markers for diastolic dysfunction. Mol Cell Biochem 376: $33-40,2013$

171. Liu X and Liu S: Role of microRNAs in the pathogenesis of diabetic cardiomyopathy. Biomed Rep 6: 140-145, 2017.

172. Lee WS and Kim J: Diabetic cardiomyopathy: Where we are and where we are going. Korean J Intern Med 32: 404-421, 2017

173. Cholesterol Treatment Trialists' (CTT) Collaborators, Kearney PM, Blackwell L, Collins R, Keech A, Simes J, Peto R, Armitage $\mathrm{J}$ and Baigent C: Efficacy of cholesterol-lowering therapy in 18,686 people with diabetes in 14 randomised trials of statins: A meta-analysis. Lancet 371: 117-125, 2008. 
174. Cosmi F and Cosmi D: Hypoglycemic therapy in heart disease patients with type 2 diabetes mellitus. G Ital Cardiol (Rome) 11: 460-466, 2010 (In Italian).

175. Anabtawi A, Moriarty PM and Miles JM: Pharmacologic treatment of dyslipidemia in diabetes: A case for therapies in addition to statins. Curr Cardiol Rep 19: 62, 2017.

176. BreaA,MillánJ,AscasoJF,BlascoM,DíazA,Hernández-Mijares A, Mantilla T, Pedro-Botet JC and Pintó X: Fibrates in primary prevention of cardiovascular disease. Comments on the results of a systematic review of the Cochrane Collaboration. Clin Investig Arterioscler 30: 188-192, 2018 (In English, Spanish).

177. Thomas CM, Yong QC, Seqqat R, Chandel N, Feldman DL, Baker KM and Kumar R: Direct renin inhibition prevents cardiac dysfunction in a diabetic mouse model: Comparison with an angiotensin receptor antagonist and angiotensin-converting enzyme inhibitor. Clin Sci (Lond) 124: 529-541, 2013.

178. Machackova J,Liu X, Lukas A and Dhalla NS: Renin-angiotensin blockade attenuates cardiac myofibrillar remodelling in chronic diabetes. Mol Cell Biochem 261: 271-278, 2004.

179. Bangalore S, Messerli FH, Kostis JB and Pepine CJ: Cardiovascular protection using beta-blockers: A critical review of the evidence. J Am Coll Cardiol 50: 563-572, 2007.

180. Sharma V and McNeill JH: Parallel effects of $\beta$-adrenoceptor blockade on cardiac function and fatty acid oxidation in the diabetic heart: Confronting the maze. World J Cardiol 3: 281-302, 2011.

181. Mohamad HE, Askar ME and Hafez MM: Management of cardiac fibrosis in diabetic rats; the role of peroxisome proliferator activated receptor gamma (PPAR-gamma) and calcium channel blockers (CCBs). Diabetol Metab Syndr 3: 4, 2011.
182. Ellestad MH: Hyperbaric oxygen: Its application in cardiology: A historical perspective and personal journey. Cardiol Rev 17: 280-282, 2009.

183. Karadurmus N, Sahin M, Tasci C, Naharci I, Ozturk C, Ilbasmis S, Dulkadir Z, Sen A and Saglam K: Potential benefits of hyperbaric oxygen therapy on atherosclerosis and glycaemic control in patients with diabetic foot. Endokrynol Pol 61: 275-279, 2010.

184. Katare R, Caporali A, Zentilin L, Avolio E, Sala-Newby G, Oikawa A, Cesselli D, Beltrami AP, Giacca M, Emanueli C and Madeddu P: Intravenous gene therapy with PIM-1 via a cardiotropic viral vector halts the progression of diabetic cardiomyopathy through promotion of prosurvival signaling. Circ Res 108: 1238-1251, 2011.

185. Cheng Y, Guo S, Liu G, Feng Y, Yan B, Yu J, Feng K and Li Z: Transplantation of bone marrow-derived endothelial progenitor cells attenuates myocardial interstitial fibrosis and cardiac dysfunction in streptozotocin-induced diabetic rats. Int J Mol Med 30: 870-876, 2012

186. Neel S and Singla DK: Induced pluripotent stem (iPS) cells inhibit apoptosis and fibrosis in streptozotocin-induced diabetic rats. Mol Pharm 8: 2350-2357, 2011. 